http://dx.doi.org/10.18778/7969-409-9.03

Sebastian Żurowski*

\title{
Kontekstowa interpretacja wyrażeń o tzw. znaczeniu ogólnym
}

\section{Wprowadzenie}

Przedmiotem opisu w niniejszym rozdziale są wybrane aspekty związane ze zjawiskami definiowanymi w literaturze przedmiotu m.in. jako zaimkowość czasownikowa (zastówkowość, prowerbalnośćn ), zob. Nitsch (1926a, 1955: 335338), tentegowanie, zob. Sobierajski (1960), językowe jokery, zob. Jawór (2010), czy wreszcie komunikacja bezrefleksyjna, zob. Fleischer i in. (2011) ${ }^{2}$.

$\mathrm{Z}$ formalnego punktu widzenia $\mathrm{z}$ wyrażeniami o znaczeniu ogólnym mamy do czynienia wtedy, gdy w wypowiedzeniu czasownik ${ }^{3}$ o konkretnym znaczeniu leksykalnym (np. bić) jest zastępowany hiperonimem o znacznie szerszym znaczeniu (np. robić). Jednocześnie jednak bezpośredni kontekst zdaniowy i/lub sytuacyjny pozwala odbiorcy komunikatu dokonać właściwej interpretacji sensu wypowiedzenia. Ale droga prowadząca do pojawienia się w tekście w funkcji hiperonimów elementów leksykalnych typu tentegować, które najczęściej bywają w literaturze językoznawczej nazywane zaimkami czasownikowymi, jest stosunkowo długa. Ich źródłem jest zjawisko żywej mowy, które Sobierajski (1960: 32) nazwał tentegowaniem:

Powtarzanie takie [wyrazu lub zdania - przyp. S.Ż.] wynika przeważnie z braku kompetencji co do dalszej wypowiedzi, ma więc wypełnić lukę, jaka by musiała powstać w toku opowiadania, gdyby tego powtórzenia nie stosować. Podobną funkcję

* Zakład Teorii Języka, Instytut Języka Polskiego, Wydział Filologiczny, Uniwersytet Mikołaja Kopernika w Toruniu, ul. Fosa Staromiejska 3, 87-100 Toruń.

1 Proponowany termin angielski, który oddaje istotę zjawiska, a jednocześnie pozwala uniknąć homonimii z tradycyjnym proverb 'przysłowie', to proverbality, zob. Żurowski (2012).

2 Żaden z przywołanych terminów nie obejmuje dokładnie pola badawczego, które będzie przedmiotem opisu. Stosunkowo najbliżej niego jest zaimkowość czasownikowa, a najdalej - komunikacja bezrefleksyjna.

$3 \mathrm{~W}$ języku polskim występują również rzeczowniki, których znaczenie jest stosunkowo ogólne (wihajster. dyngs, onaczydło etc.). 
spełnia wtrącanie różnych porzekadeł [...] i tzw. tentegowanie, tj. wtrącanie zaimka wskazującego ten, ta, to lub dopełniacza tego, gdy mówiący nie może sobie przypomnieć nazwiska osoby czy nazwy jakiegoś przedmiotu lub czynności [...]. O wiele częściej w takiej funkcji występuje „ekanie”, czyli wtrącanie dłużej lub krócej przeciąganej samogłoski $e[. .$.$] . „Przejęzyczenie”, czyli urywanie wyrazu lub zdania$ często jest wynikiem dbałości o uściślenie wypowiedzi [...].

Tentegowanie jest zjawiskiem nadal żywym (i nie tylko gwarowym), co dokumentują też teksty mówione znajdujące się w elektronicznych zasobach Narodowego Korpusu Języka Polskiego ${ }^{4}$ : no wiesz. no i tego. no i już wiesz pan pana Mariusza podstawita pod ściana; on byt taki on byt też taki złoty medalista że tego że wiesz ten jeden skok w sumie nie?; i poszedt do składziku... No $i$ on idzie do piwnicy, $i$ tego, $i$ tam jest zamknięte; I wczoraj, ten, widziatem się z Edzią. A on na to, że tego, że nie ma kasy. Badacz języka mówionego wskazałby w przytoczonych wypowiedziach wiele cech strukturalnych, które przypisuje się tzw. żywej mowie (powtarzanie spójników, elementy fatyczne, powtórzenia). Większość tych zjawisk trudno opisać w sposób formalny5. Zaznaczone elementy to właśnie przejawy tentegowania. Jego związek z ciągami typu tentegować jest ścisły nie tylko na poziomie etymologicznym (gdzie jest wręcz oczywisty), lecz także na poziomie pełnionych funkcji tekstowych. Przywołany dłuższy cytat (Sobierajski 1960) ${ }^{6}$ doskonale pokazuje, że autor umieścił to zjawisko wśród faktów mowy, które są związane z częstym w czasie tworzenia tekstu oralnego zapominaniem pojedynczych słów, fraz, a nawet całego dalszego zaplanowanego toku wypowiedzi. O tym aspekcie zjawiska można przeczytać praktycznie we wszystkich pracach teoretycznych i słownikach, w których o wtrącaniu zaimków się wspomina? ${ }^{7}$ Tak rozumiane tentegowanie jest pierwszym etapem na drodze do pojawienia się w tekstach wyrażeń czasownikowych o znaczeniu ogólnym typu tentegować.

${ }^{4}$ Ortograficzne i interpunkcyjne niekonsekwencje zapisu są cechą oryginalnych transkrypcji wykorzystanych w NKJP. W czasie prac na zasobem teksty nie były w żaden sposób poprawiane, ponieważ zasadą było nieingerowanie w teksty transkrybowane umieszczane w korpusie. Pewna normalizacja tych zapisów jest planowana w przyszłości (Pęzik 2012: 46-47).

5 Przykładową próbą formalnego podejścia do ujmowania tzw. przerywników jako osobnej klasy części mowy są np. prace Śledź (2000, 2003).

${ }^{6}$ Podobne charakterystyki można odnaleźć także w późniejszych pracach autora: „zaimek wskazujący to jest tu namiastką wyrazu nieść lub ciagnąć, który informatorowi nie przychodzi w porę do głowy; taką osobliwość języka mówionego nazywam tentegowaniem" (Sobierajski 1985: 178), „zaimek wskazujący ten zamiast nazwy futro, której mówiący nie może sobie natychmiast przypomnieć; taki rodzaj porzekania nazywam tentegowaniem" (Sobierajski 1990: 36).

7 W ISJP tentegowanie (oczywiście nie używając tego wyrażenia - w tym słowniku w ogóle nie ma artykułu tentegować) scharakteryzowano tak: „Słów ten, tego i innych form zaimka ten używamy w potocznej polszczyźnie mówionej, poprzedzając nimi wyraz, którego chwilowo nie możemy sobie przypomnieć". 


\section{Zaimkowość czasownikowa w literaturze przedmiotu}

Myśl o tym, że można wyodrębnić pewną klasę wyrażeń, które zgodnie z tradycyjną definicją zaimka są używane „zastępczo” w stosunków do czasownika, w polskim językoznawstwie pojawiła się w 1926 r. dzięki Nitschowi (1926a, 1926b). Proponował on, aby do klasyfikacji części mowy dodać nowy typ zaimka, który nazwał zaimkiem czasownikowym lub - alternatywnie - zastówkiem i proverbum. Zdaniem tego autora, zasób wyrazów, które tworzą tę klasę, jest następujący: tentegować (określone jako ,inteligenckie”), onaczyć (gwarowe), robić, być, stać się, dziać się, czynić (,sztuczne”). Jak widać, można było tu nawet wyczytać informacje, które obecnie nazwano by kwalifikatorami pragmatycznymi.

Choć podówczas myśl Nitscha wywołała pewien odzew i została podchwycona przez innych językoznawców ${ }^{8}$, to zastówki nie weszły do podręczników gramatyki i zostały właściwe zapomniane ${ }^{9}$. Dopiero Pisarkowa wzięła ponownie pod uwagę ich istnienie, ale ostatecznie (w zasadzie bez jakiejkolwiek analizy) problem wyrazów typu tentegować uznała (1969: 26) za leksykalny, jako że są to po prostu czasowniki o bardzo ogólnym znaczeniu ${ }^{10}$ :

Zagadnienie, czy można mówić o proverbum w postaci jakiegoś czasownika o bardzo szerokim znaczeniu, np. tentegować, pieprzyć itp., uważam za leksykalne i nienależące do poruszanej tu problematyki [analizy funkcji składniowych zaimków jako odrębnej części mowy - przyp. S. Ż.].

Nieco innego zdania niż Pisarkowa byli Kempf(1972) i Jodłowski (1973: 38). Ten drugi, co prawda, jak Pisarkowa, nie traktował tentegować jako zaimka, ale jednocześnie taką klasę zaimków (czasownikowych czy też czynnościowych)

8 Na łamach „Języka Polskiego” artykuły napisane w nawiązaniu do tekstu Nitscha opublikowali Doroszewski (1926) i Szober (1926). Wszyscy trzej językoznawcy podawali różne przykłady czasownikowej zaimkowości z innych języków (angielskiego, chorwackiego i francuskiego). Ponadto Doroszewski zwracał na przykład uwagę na to, że zaimki tego typu na pewno są młodsze od innych typów zaimków, a Szober wspominał, że pisał o takich możliwych zastępnikach czasowników już w 1908 r., choć nie ujmował ich w swoich podręcznikach gramatyki (zatem de facto przypisywał sobie pomysł Nitscha).

9 To, że w powojennym polskim językoznawstwie powszechnie nie uznawano sensowności wyodrębniania zaimków czasownikowych, potwierdza Bańko (2001: 203), pisząc, że „zazwyczaj nie włącza się do zaimków wyrazów używanych zastępczo wobec czasowników".

${ }^{10} \mathrm{O}$ sposobie komunikacji, który polega na przekazywaniu wielorakich sensów za pomocą niewielkiej liczby czasowników o ogólnym znaczeniu, prawdopodobnie pierwszy pisał Kucała (1960: 152). Mówił on o wulgaryzmach (wymieniając jedynie pieprzyć), że używane są często, ponieważ są ekspresywne i można nimi bez wysiłku zastępować inne słowa. Najnowszą próbą opisania tego rodzaju komunikacji jest zespołowe opracowanie nazwane „słownikiem polszczyzny rzeczywistej”, zob. Fleischer i in. (2011). Rejestruje się w nim funkcje komunikacyjne (znaczenia kontekstowe) słów chuj, jebać, kurwa i pierdolić (oraz derywatów) w kontekście m.in. tzw. komunikacji bezrefleksyjnej opisanej wcześniej ma gruncie nauk społecznych przez Langer. 
wyodrębnił. Umieścił w niej kształty takie jak natego, potego, przytego, roztego, tego, tentego (czyli w zasadzie tego z różnymi prefiksami). Argumenty Jodłowskiego nie są wcale nieprzekonujące. Zastówki w jego rozumieniu nie są czasownikami, ponieważ zawierają element typowo zaimkowy tego, mają charakter wskazujący lub zastępczy i - przede wszystkim - morfologicznie nie są czasownikami (nie podlegają koniugowaniu).

W swoich pracach poświęconych językowi mówionemu także Bartmiński (1974: 229) posługuje się terminem zaimek czasownikowy: „W języku potocznym istnieją obce polszczyźnie pisanej swego rodzaju zaimki czasownikowe, tzn. substytuty, ogólnikowe zastępniki pełnych znaczeniowo nazw czasownikowych". W tym cytacie widać jeszcze znaki dystansowania się od terminu (wyrażeniem swego rodzaju), ale później (1978: 166) autor przywołuje już znany tekst Nitscha i doprecyzowuje, że zasłówki tworzą tzw. orzeczenie zaimkowe, które jest charakterystyczne dla wypowiedzi improwizowanych i nieporadnych.

Na jeszcze inne aspekty zasłówków zwrócił uwagę Bobrowski (1982; 1985: 24-29). Podzielił on zbiór czasowników przywołanych przez Nitscha na dwie wyraźnie osobne grupy ${ }^{11}$ : czasowniki, które mogą w zdaniu zastąpić dowolny czasownik (typ tentegować) i czasowniki anaforyzujące (typ robić) $)^{12}$. Różnicę między tymi typami pokazują poniższe przykłady:

Widły? Prusacka to metoda - widłami wroga tentegować. (Internet)

Jeżeli Janek przeczyta lektury, to zda egzamin, jeżeli tego nie zrobi, to nie powinien nawet próbować.

Swoistą syntezą ${ }^{13}$ wszystkich dotychczasowych pomysłów interpretacyjnych było podejście Topolińskiej (1989: 97-98; 2008: 159-160). Wśród faktów językowych, które można nazwać (z różnych powodów) zaimkowością czasownikową, wyróżnia ona trzy zjawiska:

a) konstrukcje złożone z zaimków wskazujących/pytajnych i „maksymalnie semantycznie ubogich czasowników": Co robisz? Właśnie to robię. Co się dzieje? To się stało wczoraj;

${ }^{11}$ Ta osobność była na tyle wyraźna, że już dużo wcześniej Kempf (1972: 163-165) podzielił je na (funkcjonalnie tożsame z grupami Bobrowskiego) zaimki czasownikowe zależne (kontekstowe) i niezależne. Ponadto z powodu różnej ich budowy formalnej mówił o czasownikach o funkcji zaimkowej i czasownikach odzaimkowych.

${ }^{12}$ Przy czym czasowniki z grupy pierwszej mogą także pojawiać się w funkcji anafory, choć na nieco innej zasadzie (Bobrowski 1982: 128-129). Problemy związane z anaforyzacją przez czasowniki (z)robić, (u) czynić analizowali także Chachulska (1999) i Niziołek (2001).

${ }^{13}$ Dla porządku trzeba dodać, że Topolińska nie przywołuje większości pozycji bibliograficznych, które są referowane w tym paragrafie. Wśród odsyłaczy bibliograficznych w jej artykułach poświęconych problemowi odnaleźć można właściwie jedynie artykuł Kempfa (1972). 
b) konstrukcje morfologiczne oparte na rdzeniach zaimków wskazujących polskie: tentegować; czeskie: tentovat; łużyckie: wonoźyś; macedońskie: онадu; czarnogórskie gwarowe: onodi; słoweńskie: onegati, onegaviti;

c) zredukowane potwierdzające repliki dialogowe w postaci form tzw. czasowników pomocniczych (w językach: serbskim, chorwackim, słoweńskim, łużyckim $\left.{ }^{14}\right)$.

Widać, że zaimkowość czasownikowa jest tu rozumiana bardzo szeroko ${ }^{15}$. O trzeciej grupie wyrażeń (w języku angielskim i serbsko-chorwackim) stosunkowo dokładnie pisał już Kempf (1972). Kilka prac poświęciła im także - w całości lub częściowo - Topolińska (1982; 1989; 2008: 66-76; 2008: 159-165).

Klasę wyrażeń o nazwie proverba (ProV) wyróżnił i wstępnie opisał Piernikarski (1990: 197-202). Wprost pisał on tym, że ProV są semantycznie ,absolutnie” puste i mogą zastępować w tekście dowolne czasowniki czynnościowe w sytuacji, gdy mówiącemu zabraknie właściwego czasownika lub gdy chce zwiększyć ekspresję wypowiedzi. Dosyć dziwne jest jednak to, że jako przykłady Piernikarski podaje tylko czeskie tentovat ${ }^{16}$ i polskie tego, potego, pokazując, że funkcjonalnie są identyczne, mimo różnic morfologicznych. W swoim szkicowym opisie bierze pod uwagę w zasadzie wszystkie trzy wspomniane typy prowerbalności, o której pisała Topolińska ${ }^{17}$, ale prezentuje bardzo ograniczony materiał egzemplifikacyjny.

Niekiedy w literaturze językoznawczej termin zaimek czasownikowy nie jest definiowany w jakikolwiek ścisły sposób i używany jest $w$ zasadzie jako figura retoryczna. Tak jest np. w pracy Bugajskiego (2006: 219-220):

\begin{abstract}
Wiele [...] znaków językowych (o zmienionym znaczeniu czy wręcz pustych wyrazów i ich związków) pojawia się w środkach masowego przekazu, stamtąd zaś przenika do tekstów języka potocznego. Przyczyną, bodajże najważniejszą, tego stanu rzeczy jest nieuświadamianie sobie związku między znakiem językowym a jego znaczeniem, traktowaniem jako znaku tylko jednego elementu układu - elementu znaczącego. W ten sposób wiele wyrazów, które do niedawna jeszcze miały znaczenie dość konkretne, przestaje w ogóle znaczyć, na przykład takie czasowniki, jak: prowadzić, realizować, wykonać, zabezpieczyć we współczesnej polszczyźnie pełnią rolę „zaimków czasownikowych".
\end{abstract}

${ }^{14}$ Wymienione są tu tylko języki słowiańskie. Na ten typ „zaimkowości” wcześniej uwagę zwrócił z kolei jeszcze Doroszewski (1926) w języku angielskim. Chodzi o wszelkie użycia form czasownika to do jako replik potwierdzających lub zaprzeczających.

${ }^{15}$ Samą zaimkowość czasownikową można rozumieć jeszcze szerzej niż Topolińska. Segmenty czasownikowe o bardzo ogólnym znaczeniu (w każdym razie bardzo trudnym do wyspecyfikowania) pełnią funkcję słów posiłkowych w tzw. analityzmach werbonominalnych, zob. SZWN, Żmigrodzki (2000). Poza tym Topolińska nie bierze pod uwagę wyrażeń z grupy zaimków czasownikowych wyróżnionych przez Jodłowskiego.

${ }^{16}$ Podobnie charakteryzuje ten czeski czasownik już w monografii poświęconej aspektowi czasownika polskiego (1969: 29).

${ }^{17}$ Prace Topolińskiej są mu jednak prawdopodobnie nieznane. W odsyłaczach przywołuje tylko koncepcję Jodłowskiego. 
Najnowsza interpretacja leksykologiczna czasowników o znaczeniu ogólnym, zob. Żurowski (2010, 2011, 2012), zakłada, że kształty typu tentegować, onaczyć, smerfować nie konstytuują leksykalnych jednostek języka, ale są wykładnikami asemantycznych operacji (nieleksykalnych jednostek języka ${ }^{18}$ ), których istotą jest zastąpienie $\mathrm{w}$ zdaniu wyjściowego morfologicznego czasownika (z pozostawieniem ewentualnego prefiksu i postfiksu) wybranym kształtem typu tentegować przy zachowaniu znaczenia czasownika wyjściowego. Znaczenie to może być odtworzone kontekstowo (z bardzo dużym prawdopodobieństwem trafności) przez odbiorcę dzięki temu, że powstałe wyrażenie ma taką samą strukturę predykatowo-argumentową jak czasownik wyjściowy (i może mieć także jego prefiks i postfiks). Przykład:

\section{Zdaje się, że Maco mają otwieralne/wymienne kasetki. Się wieczko tenteguje i można film wyjąć. (Internet)}

Bez większego trudu można powiedzieć, że wyrażenie się tenteguje w tym wypadku maskuje jednostkę [ktoś] otwiera [coś], a stanem wyjściowym byłby tekst:

Zdaje się, że Maco mają otwieralne/wymienne kasetki. Się wieczko otwiera i można film wyjąć.

Oczywiście tekst ten nigdy nie został przez autora oryginalnej wypowiedzi wypowiedziany ani napisany w takiej „odtworzonej” postaci. Zamiana jest operacją, z której korzysta się w toku tworzenia tekstu, nie w celu modyfikacji już gotowej wypowiedzi. W niniejszym opracowaniu ten pomysł interpretacyjny czasowników typu tentegować zostanie utrzymany i rozwinięty. Na określenie tego typu faktów leksykalnych stosowany będzie termin asemantyczne operacje zastówkowe (AOZ). Jednocześnie nie będą tu opisywane zjawiska wyliczone przez Topolińską w grupach a) i c), ponieważ są to zjawiska bardziej składniowe niż leksykologiczne (czyli bardziej semantyczne, a mniej pragmatyczne).

\section{Zasób wykładników AOZ}

Choć wydaje się to paradoksalne, brak w wypowiedzi znaczących czasownikowych rdzennych morfemów leksykalnych nie jest aż tak dużą przeszkodą w potocznej komunikacji. W 1969 r. Melchior Wańkowicz opublikował na łamach „Polityki” felieton Stowa-wytrychy, który został potem przedrukowany

${ }^{18}$ Terminy jednostka języka i asemantyczna jednostka operacyjna wykorzystywane są w znaczeniu nadanym im przez Bogusławskiego (1976, 1994). 
w Karafce La Fontaine'a. Przytoczył w nim (2010: 223) - rzekomo autentyczny wykład ogniomistrza baterii działek przeciwpancernych we Włoszech z czasów II wojny światowej:

Odpieprzacie zamek, przepieprzacie lufę wyciorem, wpieprzacie pocisk, przepieprzacie iglice, zapieprzacie zawór, napieprzacie na cel, wypieprzacie pocisk, podpieprzacie drugim, i czołg - rozpieprzony. Jak spieprzycie, to już was porucznik opieprzy. Zrozumiano?

Dalej autor dodaje jeszcze, że zastąpił czasownikiem pieprzyć inny, „właściwszy wojsku” i ,bardziej plastyczny”. Czy to w powyższej wersji „eufemistycznej”, czy w wersji z pierdolić, „wykład” ten jest znakomitym przykładem budowania komunikatu za pomocą operacji zastępujących wyjściowe pełnoznaczne czasowniki czynnościowe ${ }^{19}$. Byłby on tak samo informatywny (choć zdecydowanie mniej ekspresywny) nawet w wersji z tentegować czy nawet (sic!) smerfować:

Odsmerfowujecie zamek, przesmerfowujecie lufę wyciorem, wsmerfowujecie pocisk, przesmerfowujecie iglicę, zasmerfowujecie zawór, nasmerfowujecie na cel, wysmerfowujecie pocisk, podsmerfowujecie drugim, i czołg - rozsmerfowany. Jak zesmerfujecie, to już was porucznik osmerfuje. Zrozumiano?

Odpowiedź na pytanie, jaki jest zasób ciągów znaków, które mogą pełnić funkcję ,zaimków czasownikowych” (wykładników AOZ), wcale nie jest prosta. Problemów jest kilka. Po pierwsze, z reguły wyrażenia takie nie są rejestrowane w słownikach ogólnych języka, ponieważ należą do warstw stylistycznych, które są w takich słownikach rejestrowane słabo (gwary, język potoczny, wulgaryzmy). Po drugie, ich ,wszystkoznaczność" powoduje istotną trudność z uchwyceniem znaczeń słownikowych. Po trzecie, istotą AOZ jest to, że ciąg znaków maskujących właściwy czasownik może być w gruncie rzeczy dowolny, co daje pewne możliwości stylistyczne.

Mimo wyliczonych trudności, można wyróżnić kilka wyraźnych grup wyrażeń o morfologii czasownika, które są ewidentnymi wykładnikami AOZ. Najważniejsza ich grupa to zasłówki genetyczne. Ich etymologia (nie tylko w języku polskim, ale też w innych językach słowiańskich) związana jest $\mathrm{z}$ rdzeniami zaimkowymi, co pozwala przypuszczać, że wywodzą się one wprost z tentegowania. Do tej grupy na pewno należą następujące wyrażenia: polskie - tentegować, tegować, tegocić, onaczyć, torobić; czeskie - tentovat, ondati; słowackie - onditi, ondziti, ondiati; łużyckie - wопоźyś; macedońskie - онади; czarnogórskie - onodi; słoweńskie - onegati, oniegaviti. Topolińska twierdzi, że tego rodzaju konstrukcje morfologiczne występują we wszystkich językach południowoi zachodniosłowiańskich, jednak sama nie podaje przykładów spoza powyższej

\footnotetext{
${ }^{19}$ Operacja zasłówkowa w zasadzie działa wyłącznie na czasownikach czynnościowych (czyli takich, które w swojej strukturze semantycznej mają komponent (z)robić).
} 
listy (nie podaje też przytoczonych przykładów słowackich). Nie można z pewnością powiedzieć, że lista jest kompletna, ponieważ do stwierdzenia obecności w danym języku zasłówków genetycznych wymagana jest znajomość nie tylko ogólnej odmiany danego języka, lecz także jego gwar ${ }^{20}$. Czasowniki typu tentegować - przynajmniej część z nich - na pewno są etymologicznie stare, za czym przemawia ich tożsama postać we wszystkich językach oraz korzenie gwarowe. Ich obecność w języku ogólnym jest wtórna. Są one też całkowicie obce - tak jak widział to Bartmiński - językowi pisanemu. Oto przykłady - czeski, słoweński i polski - typowych użyć zastówków genetycznych, użytych w znaczeniach 'wyrzucić', 'kochać się' i 'wydalić':

Musiš to vytentovat! - Už jsem to dávno vytentoval. (Piernikarski 1990: 198)

Nekega dne pa sem nenadoma zavohal, da Mira tudi z drugim onegavi. (Topolińska 1987: 160)

Koniki, rozumiesz, wszystko zjadły. Przeżarły i wytentegowały w postaci nawozu.

(T. Konwicki, Spowiedź, 1960)

Przywołany czasownik przypisany językowi czarnogórskiemu - onodi w pracy Topolińskiej (1989) jest klasyfikowany jako słowo serbochorwackie z gwar czarnogórskich. Z perspektywy 1989 r. było to stwierdzenie zgodnie z ówczesną nomenklaturą, gdyż oczywiście nie wyróżniano języków: serbskiego, chorwackiego, czarnogórskiego i bośniackiego. Jednak prawdopodobnie dokładne spenetrowanie obszarów dialektalnych wykazałoby, że takie lub podobne zasłówki występują na innych terenach byłej Jugosławii niż Czarnogóra, Macedonia i Słowenia ${ }^{21}$. Bardzo pouczający jest przykład polskiego dialektalnego (z Małopolski) torobić. Wzmiankę o tym czasowniku można odnaleźć tylko w jednej pracy (w dodatku niejęzykoznawczej) - jest to fragment wspomnień literaturoznawcy Józefa Spytkowskiego (1975), który ze swojego dzieciństwa spędzonego na wsi podkrakowskiej zapamiętał, że używano tam czasowników o znaczeniu ogólnym torobić, onaczyć i tentegować (w różnych formach prefiksalnych na wy-, przy-, od-, do- i roz-). Przy czym owo torobić było używane przez osoby starsze, a tentegować przez młodsze pokolenie. Zgodnie z relacją autora, torobić oznaczało wykonywanie czynności raczej skomplikowanej. Wyrażenie to nie jest znane w języku ogólnym i nigdy znane nie było. Nie wspomina o nim żaden z autorów, którzy w 1926 r. na łamach „Języka Polskiego”

${ }^{20}$ Co więcej, wielu rodzimych użytkowników języka polskiego nie będzie znało wszystkich tych czasowników, które wymienione zostały jako wyrażenia języka polskiego. Podobnie nie wszyscy przepytywani użytkownicy (w tym rodzimi) języka czeskiego znają podane wyrażenia czeskie czy słowackie.

${ }^{21} \mathrm{~Np}$. nie da się odnaleźć ich w południowosłowiańskich tekstach gwarowych przedrukowywanych przez Sławskiego (1962), ale może to oznaczać też po prostu tylko to, że źródło nie jest wystarczająco obszerne. 
wypowiadali się na temat zaimków czasownikowych. Nie jest wykluczone, że więcej takich torobić jest ,poukrywanych” w dialektach słowiańskich (może także wschodnich).

Druga - bardzo wyrazista - grupa zasłówków to zastówki wulgarne. Przykładem ich funkcjonowania jest przywoływany już fragment wzięty z pism Wańkowicza. Jeszcze większy zasób przykładów „pansemantyczności” wypowiedzi konstytuowanych jedynie na rdzeniach wulgarnych przywołują Fleischeri in. (2011). Wieloznaczność czasowników wulgarnych (która jest konsekwencją tego, że są one semantycznie puste, a „znaczenie” uzyskują dopiero w kontekście ${ }^{22}$ ) jest czymś uniwersalnym. Zasadniczy sens wykładu ogniomistrza oraz jego językowy aspekt (korzystanie wyłącznie z jednego czasownika) da się odtworzyć np. w języku angielskim:

You fuck off the lock, fuck the barrel through with cleaning rod, fuck the missile in, fuck the needle thorugh, fuck the valve up, fuck at the target, fuck out the missile, fuck it up by the second one, and tank - is fucked up. If you fuck away, then the lieutenant will fuck you off. Got it?

Nieco zaskakujące może być to, że bardzo wyraźną podgrupą zasłówków (zaliczyć je można do zasłówków wulgarnych, ale z zastrzeżeniem, że nie jest to wulgarność „najsilniejsza”, czyli systemowa czy kakofemiczna), stanowią czasowniki derywowane od nazw... pikantnych przypraw kuchennych. Chodzi przede wszystkim o pieprzyć, chrzanić i pierniczyć, ale w pewnych kontekstach funkcjonują także inne kulinaria, np. przyfasolić, skaszanić etc., zob. Jawór (2010).

Zasób genetycznych i wulgarnych zasłówków jest zamknięty - nie zmieni tego faktu nawet ewentualne wskazanie jeszcze jakichś innych elementów, które nie zostały wspomniane powyżej. Jednak istota $\mathrm{AOZ}$ polega też m.in. na tym, że do zastąpienia wyjściowego „pełnoznacznego” czasownika można wykorzystać w zasadzie dowolny element dźwiękowy lub graficzny. Rezultaty takiego twórczego podejścia do systemu języka (systemu, ponieważ AOZ są jednostkami systemowymi) określić można etykietką zasłówki okazjonalne.

Istnieje interesujący polski tekst literacki, który poniekąd jest potwierdzeniem proponowanego w tym opracowaniu sposobu interpretacji kształtów typu tentegować, czyli potwierdza systemową niemożność przypisania im sensownie jakiegokolwiek znaczenia. Ten tekst to satyryczne opowiadanie Czmyr profesora Śledzika (2006) z tomiku Człowiek zwany biurkiem. Opowiadania ćwierćabsurdalne, które sygnowane jest pseudonimem Niżej Podpisany. Bohaterem tego

22 Por. stwierdzenie: „O ile można zgodzić się z poglądem, że przekleństwa nie posiadają znaczenia, nazwijmy go, leksykalnego, o tyle podkreślić tu chcemy, że bez wątpienia posiadają znaczenie komunikacyjne oraz spełniają funkcję pansemantyczności” (Fleischer i in. 2011: 37). 
opowiadania jest profesor Konrad Słodzik, „najwybitniejszy polski językoznawca", który próbuje dotrzeć do znaczenia słowa czmyrać. Słowa, które jest przez niego coraz częściej słyszane w sytuacjach życia codziennego. Te próby semantyczne nie są jednak zbyt udane:

\begin{abstract}
Profesor zaczął zdradzać, jak sam mówił, objawy „,zaawansowanego poczmyrania nerwowego". Skłaniał się coraz bardziej do postawienia tezy, że nowe wyrażenie znajduje równie powszechne zastosowanie, co „tentego" - podstępne słówko, które doprowadziło profesora Poniewiarczyna do śmierci ze zgryzoty, ale i spowodowało zwiększenie zatrudnienia w dziale analiz Wydawnictwa Słownikowego. Liczba archiwistów i łowców znaczeń „tentego" zwiększyła się tam trzykrotnie, a następca Poniewiarczyna, magister Dołek, wydał na ich podstawie bestsellerową książkę Słownik Naszej Tentegowszczyzny. Karierę na fali tentego zjawiska zrobił również wcześniej dosyć źle odbierany poeta Klimoński, który na łamach Notatnika Poetyckiego opublikował wiersz Przytenteguj ten tego stanowiący początek wkółkomaciejizmu w poezji polskiej. (N. Podpisany, Czmyr profesora Śledzika, 2006)
\end{abstract}

W tekście są liczne przykłady zdań z czasownikiem czmyrać. Choć jest on neologizmem, który nie może być znany żadnemu, nawet rodzimemu, użytkownikowi języka polskiego, nie ma większych trudności z rozpoznaniem znaczeń tych konkretnych wypowiedzi: Czmyrnij się po piwo, miło, czmyrnij, ale już!; Jak tego nie wyczmyram, to zwariuje!; Jeszcze troche poczmyram i spadam na podwórko; Nie czmyraj mnie, bezbożniku!; Odczmyraj to, bo cię czmyrnę!; Przepraszam szefie, jeszcze nie rozczmyratem tematu.

Przywołane opowiadanie nie jest tekstem powszechnie znanym. Zdecydowanie bardziej znanym przykładem artystycznej kreacji w polu AOZ jest smerfować / smurfować. Jednocześnie jest to przypadek o tyle szczególny, że mamy tu do czynienia z internacjonalizmem, który z tekstów literackich (a za takie należy uznać komiksy - choć w Polsce oczywiście popularność tym postaciom przyniosła seria telewizyjna), przeszedł do wielu języków świata ${ }^{23}$. Na gruncie języka polskiego najczęściej pojawiającym się w języku potocznym słowem wywodzącym się z ,języka Smerfów” jest prawdopodobnie smerfy 'policjanci'. Co ciekawe, także w języku prawniczym występuje termin smerfowanie (ang. smurfing). Takie określenie przyjęto w literaturze przedmiotu na nazwanie jednego ze sposobów tzw. prania brudnych pieniędzy, zob. Dean, Fahsing, Gottschalk (2010: 53-55) ${ }^{24}$. Taką samą postać ma także termin z zakresu informatyki, gdzie oznacza z kolei jeden z rodzajów ataków hakerskich, zob. Kizza (2011: 78).

${ }^{23}$ Wystarczy zastosować podstawową operację słowotwórczą, która tworzy z rzeczownika czasownik, aby ,język Smerfów” mógł pojawić się w dowolnym języku. W języku angielskim jest to dodanie wykładnika to, w językach słowiańskich sufiksu -ować, zob. angielskie to smurf, polskie smerfować, czeskie šmoulovat, łużyckie šlumpfować, serbskie štrumpfovati etc.

${ }^{24}$ Termin ten przyjęty jest także w polskiej literaturze przedmiotu, zob. Wójcik (2007: 234). 


\section{Próba przypisania znaczenia czasownikom o znaczeniu ogólnym}

Potwierdzenia wymaga to, czy rzeczywiście nie jest możliwe utworzenie „słownika naszej tentegowszczyzny”, czyli że elementy nazywane wykładnikami AOZ są semantycznie puste (tak jak piszą o tym m.in. Piernikarski i Żurowski). Wykazane to zostanie na przykładzie analizy tekstowych wystąpień ciągu tentegować.

Aby można było sensownie rozważać problem znaczenia jakiegokolwiek wyrażenia językowego, niezbędne jest zebranie jego przykładowych użyć. Jest to tym bardziej istotne w wypadku wyrażeń o wyraźnie niestandardowym zakresie użycia, gdyż nie da się badać znaczenia czasownika tentegować na przykładzie zdań preparowanych typu ${ }^{25}$ : Jaś tenteguje latawiec. Wydaje się, że tentegować powinno mieć dosyć dużą frekwencję, ale ograniczenie jego występowania do potocznego języka mówionego sprawia, że trudno o poświadczenia tego wyrazu. W tej sytuacji najlepszym źródłem materiału wydaje się Internet, gdzie na forach można odnaleźć ten czasownik stosunkowo często ${ }^{26}$.

Wszelkie wzmianki słownikowe na temat tentegować nie są do końca satysfakcjonujące. Czasownik ten z reguły jest rejestrowany w słownikach ogólnych języka polskiego, ale nie we wszystkich. Nie ma go np. w ISJP (co nie dziwi, jeśli wziąć pod uwagę, że wyrażenie to nie występuje w Korpusie PWN-u, który jest materiałową podstawą tego słownika). W SJPDor opatrzony jest kwalifikatorem pot., a przypisuje się mu definicję 'czasownik mogący być określeniem dowolnej czynności (czasem używany eufemistycznie) ${ }^{27}$. W PSWP

${ }^{25}$ Choć wydaje się, że test sprzecznościowy w tym wypadku pokazałby, że w wyrażeniu tentegować znajduje się komponent 'robić', zob. ?Jaś tenteguje latawiec, ale nieprawda, że coś robi. Tak swoje intuicje dotyczące znaczenia tentegować formułuje Lipiński (2004: 124): ,[...] jego zasadniczym znaczeniem jest tranzytywność, dokonywanie czynności przez podmiot wobec czegoś, może jednak przyjmować i inne znaczenia”. Jest to jednak wrażenie pozorne, ponieważ w takim zdaniu tentegować zastępuje właśnie czasownik robić.

${ }^{26}$ Taki materiał analizowany był w artykule Żurowski (2010). Niniejsze opracowanie bazuje nie tylko na tekstach internetowych, ale także na poświadczeniach z tekstów drukowanych (przede wszystkich literackich). Możliwą formą zbierania materiału językowego są również ankiety. W ten sposób Kowalikowa badała słownictwo młodych mieszkańców Krakowa. W jej materiale (1991a: 143, 1991b: 51) w znaczeniu 'odczep się' pojawiło się polecenie odtenteguj się oraz odtenteguj się ode mnie, natomiast postaci wytenteguj, a także wytentegowuj, stentegowuj przypisano „znaczenia” 'wynoś się, 'uciekaj', 'zmykaj'. Ten skromny zestaw znaczeń jest przykładem ograniczeń, jakie pociąga za sobą badanie ankietowe w leksykologii.

${ }^{27}$ W SJPDor w haśle tentegować nie ma żadnego przykładu, co prawdopodobne oznacza, że hasło to redaktorzy dodali na podstawie własnej kompetencji, a nie dokumentacji zebranej przy przygotowywaniu słownika. W siatce haseł SJPDor nie ma też żadnych derywatów prefiksalnych opartych na podstawie tentegować, co Wawrzyńczyk (1989: 115) uważa za brak tego dzieła leksykograficznego. 
kwalifikacja ta została utrzymana, a definicja właściwie przepisana (zmieniono jedynie wyrażenie mogacy być na będacy). Nieco bardziej rozbudowana charakterystyka tentegować znajduje się w USJP. Można tam odnaleźć następujące trzy definicje: „tentegować - 1. żart. 'czasownik będący określeniem dowolnej czynności'; 2. euf. 'o mężczyźnie: odbywać stosunek seksualny””; „tentegować się - pot. euf. "odbywać stosunek seksualny"'.

W słownikach specjalnych „seksualny” aspekt znaczenia tentegować jest też przez leksykografów podkreślany. Na przykład w gniazdowym Słowniku polszczyzny potocznej Anusiewicz i Skawiński (1996) podają prawie taki sam schemat: „1. znaczenie ogólne, 2. znaczenie 'o mężczyźnie: odbywać stosunek seksualny' i 3. tentegować się jako czasownik oznaczający 'odbywać stosunek seksualny", a w Stowniku seksualizmów polskich Lewinsona (1999) pierwsze podane znaczenie wzięte jest jeszcze z SJPDor, do którego dodano drugie: 'stosunek płciowy heteroseksualny' - już bez wyodrębniania form z się i bez się.

Najwięcej znaczeń (cztery), ale nadal w tym samym duchu, wyodrębnił Czeszewski (2006): „1. 'wyraz zastępujący inne czasowniki'; 2. 'robić coś'; 3. euf. 'o chłopaku, mężczyźnie: odbywać stosunek płciowy'; 4. [tentegować się] euf. 'odbywać stosunek płciowy, uprawiać seks"'. Tentegować pozornie pojawia się w wypowiedziach w ,znaczeniach”, które przypisują mu słowniki. Kluczową obserwacją, która jest przekonującym argumentem na rzecz tego, że nie jest możliwe wyodrębnienie żadnej leksykalnej jednostki języka opartej na ciągu znaków o takiej postaci, jest stwierdzenie, że tentegować nie ma żadnej własnej struktury predykatowo-argumentowej (którą ma każdy „normalny” czasownik). We właściwie każdym wypadku tentegować „przejmuje” układ argumentów czasownika, którego miejsce w danej jednostce języka zajęło ${ }^{28}$. Dlatego tentegować (i mutatis mutandis każdy ciąg pełniący w systemie analogiczne funkcje omówiony w poprzednim paragrafie) należy rozpatrywać nie w kategoriach jednostki leksykalnej, ale asemantycznej jednostki operacyjnej: punktem wyjścia dla tejże operacji jest zdanie z czasownikową jednostką ,,pełnoznaczną" (z normalną strukturą predykatowo-argumentową - np. [ktoś] pisze [coś]), a jej istota zasadza się na zamianie kształtu tożsamego z morfologicznym czasownikiem w wyjściowej jednostce, na kształt zasłówka genetycznego, wulgarnego lub okazjonalnego - powstaje wtedy równoznaczna docelowa struktura o postaci np. [ktoś] tenteguje [coś]. Ze względu na to, że to układ pozycji argumentów i ich wypełnienia pozwalają na odwrócenie operacji (czyli de facto na dotarcie do znaczenia tentegować w danym kontekście), w niektórych

${ }^{28}$ Wyjątkami są wątpliwe przykłady - dosyć częste w Internecie - w których mamy do czynienia z tentegowaniem $w$ głowie, np.: Po dlugim i dogtębnym procesie tentegowania $w$ głowie, postanowitem wam podziękować. Nie ma bowiem żadnego „prawdziwego” czasownika, który można by zrekonstruować w kontekście tego typu. Najbliższy jest czasownik myśleć, ale kolokacje myśleć w glowie są semantycznie dewiacyjne. 
przypadkach nie jest możliwe podanie jednego czasownika na „wejściu” operacji. Ale jeśli nie jest to możliwe, to znaczy, że nadawca niefortunnie użył wyrażenia o znaczeniu ogólnym.

Gdyby przyjąć, że ciągi typu tentegować jednak konstytuują jednostki języka z różnymi strukturami predykatowo-argumentowymi, okazałoby się, że przy ścisłym rozumieniu jednostki języka - co najmniej dwukrotnie zwiększyłby się zasób jednostek czasownikowych w systemie. Każda czynnościowa jednostka czasownikowa miałaby swój synonimiczny (nacechowany stylistycznie) odpowiednik z tentegować (a właściwie więcej odpowiedników - z tegocić, tegować, onaczyć itd.). Zupełnie niepotrzebnie „rozdymałoby” to liczebność leksykonu języka.

Interpretacji „operacyjnej” nie przeczą nawet zdania z czasownikami prefiksalnymi i z czasownikami inherentnie zwrotnymi - elementy prefiksalne moga bowiem same konstytuować morfemowe jednostki języka i ostatecznie substytucji zasłówkowej podlega element stanowiący morfologicznie rdzeń (np. przy-kleić, po-psuć, od-czepić, za-bić):

Jak chcesz daszek/okno tam przytentegować, klejem, to gdybyś miał dostęp do taśmy, co się podkleja szwy, to było by to całkiem realne. (Internet)

No, Jędruś, jak po weselu to i marynari dawaj, żeby i z drugim rękawem coś się nie potentegowało. (C. Schabowski, Nie ma ulicy Zielonej, 1972)

Skoro babci nie przeszkadza, że przejadam jej emeryturę, to Ci pieprzeni „życzliwi” mogliby się ode mnie odtentegować! (Internet)

Za... tentegować można, a nawet trzeba, ludzi odpowiedzialnych za cały ten bajzel $\mathrm{z}$ wojną i samą ideologią nazistowską. (Internet)

\section{Działanie AOZ}

Sama idea zastąpienia pełnoznacznego czasownika czynnościowego ciągiem pustym semantycznie jest prosta, ale formalny jej opis wymaga przezwyciężenia wielu trudności teoretycznych, z których pozostawienie oryginalnego prefiksu jest tylko jedną - wcale nie najpoważniejszą. Wspomniane zostało, że najbardziej prawdopodobnym źródłem AOZ jest charakterystyczne dla języka mówionego tentegowanie. Teksty drukowane wskazują, że kształt tentegować pojawił się później niż różne warianty tentegowania $\mathrm{z}$ wykorzystaniem samych form zaimkowych bez fleksji werbalnej. Zresztą elementy typu ten, tego wcale nie muszą występować w pozycji orzeczenia:

- A zdaleka pan dobrodziéj? - Ja, czy zdaleka jestem? ot tak i zblizka i zdaleka: zwyczajnie jak obieżyświat, dzisiaj tu, jutro daléj i różnie. - Aha! to pan widać bez interesu, tylko tak ten, tego, Mości dobrodzieju, dla zwidzenia, obejrzenia - i przytém lekko nachylając głowę, mocno brwi i wąsy nastrzępił. (F. Nowakowski, Wycieczka na Litwę. Wspomnienia z podróży, 1857) 
Podobne konteksty odnaleźć można w utworach Bolesława Prusa i Stefana Żeromskiego:
Musiał dobrze pójść interes [...], bo jaśnie pan coś... jakby trochę tego... (B. Prus, Lalka, 1890)
Cóż się okazało? Ten kulfon brał sprawy o tyle, o ile były ten tego z etykami, ze spra- wiedliwościami społecznemi... (S. Żeromski, Promień, 1897)

Formy ten tego (tentego, ten-tego, tego ten etc.) mogą występować w dowolnej pozycji w zdaniu, ponieważ mówiący może zapomnieć lub chcieć eufemizować dowolny element wypowiedzenia. Dlatego frekwencyjnie takie wyrażenia przeważają nad morfologicznymi czasownikami o znaczeniu ogólnym. W perspektywie diachronicznej każda operacja zasłówkowa składa się z dwóch składowych suboperacji (można też mówić o dwustopniowości tej operacji). Pierwsza suboperacja polega na zastąpieniu wyjściowego czynnościowego czasownika właściwego (z pozostawieniem ewentualnego prefiksu i postfiksu, które są ważnymi sygnałami pozwalającymi odtworzyć znaczenie wyjściowego czasownika) niefleksyjną formą typu tego, tentego. W ten sposób powstają formy, które Jodłowski nazwał zaimkami czasownikowymi:
Za takie głupstwo, za to, że się człek trochę z dziewuchom... tego?! (A. Marczyński, Strzat o świcie, 1936)
- Głupstwo, niech się pan tym nie przejmuję, kochany dyrektorze. Od dwudziestu lat tak się kłócą, znane historie. Lepiej potem tańczą. Ona pohisteryzuje, on ją tego... i w porządku. (J. Andrzejewski, Popiót i diament, 1948)
[w kopalni] labirynt, tu wykopali, tu wykopali, tu przecieka, tu przetego, tam są ozna- kowanie (Studia nad sktadnia polszczyzny mówionej, 1978)

Druga suboperacja polega na dodaniu do formy tego, tentego fleksji werbalnej (tradycyjnie w słowotwórstwie jest to derywacja paradygmatyczna ${ }^{29}$ ):

Na co burmistrz: - Dlaczego, panie radny, Parasolów pan pieprzy , a hrabiego tak ordynarnie tenteguje? Co? Mało to pałac miastu daje? A szpital? A ochronka? A kościół? A wywożenie nieczystości z naszych wychodków? Liczyć? (C. Schabowski, Zagrodniki, 1990)

Podział operacji zasłówkowej na omówione dwie suboperacje powala wyjaśnić, dlaczego nie muszą zgadzać się ze sobą wzorce koniugacyjne czasownika wyjściowego i końcowego. Tentegować zastępuje bowiem czasownik dowolnej koniugacji, ale samo ma stały, a nie zmienny paradygmat. Układ dwóch suboperacji pozwala też wyjaśnić, dlaczego niektóre wykładniki AOZ (onaczyć, smerfować) pojawiają się w tekstach mimo tego, że nie mają niefleksyjnych

\footnotetext{
${ }^{29}$ Sam opis stricte słowotwórczy tentegować jest naturalnie bardzo prosty - do podstawy złożonej ten-tego dodawany jest sufiks czasownikowy -ować (Skarżyński 1994: 99).
} 
odpowiedników. W przypadku tych dwóch wykładników (a także wykładników wulgarnych) pierwsza suboperacja jest zafiksowana (jest wyłącznie faktem etymologicznym) $)^{30}$.

\section{Funkcje pragmatyczne $\mathrm{AOZ}$}

Teza Bartmińskiego (1974: 229) o ustnym charakterze zaimków czasownikowych nie została przez niego empirycznie udowodniona, ale jest ona jak najbardziej słuszna ${ }^{31}$. Próba weryfikacji w oparciu o materiał językowy stwierdzenia, że są to elementy obce polszczyźnie pisanej, prowadzi nawet do mocniejszej hipotezy: są to elementy występujące wyłącznie w tekstach mówionych. Ich pojawianie się w piśmie związane jest z dwoma zjawiskami: metatekstem (rozumianym jako mówienie/pisanie o znakach języka) oraz zacieraniem granicy między mową a pismem w pewnych gatunkach tekstów pisanych. Dzięki tym dwóm czynnikom wiele elementów prymarnie mówionych jest inkorporowanych do tekstów pisanych. Bezdyskusyjnie tekstowe wykładniki operacji zasłówkowych występują w pięciu typach tekstów pisanych:

- transkrypcjach tekstów mówionych (także gwarowych);

- internetowych tekstach „mówionych zapisanych” (blogi, czaty, fora, posty etc.)

- tekstach artystycznych;

- pracach filologicznych (językoznawczych i literaturoznawczych);

- słownikach ogólnych i specjalnych.

To, że wykładniki operacji zasłówkowych występują w wymienionych typach tekstów pisanych, w żaden sposób nie przeczy tezie o ich wyłącznie mówionym charakterze. W przypadku transkrypcji oczywiste jest, że ma się do czynienia zawsze z zapisanym tekstem mówionym (choć już inaczej będzie ze stenogramami). Nieco mniej oczywiste jest to w wypadku tekstów internetowych, ale też twierdzenia pojawiające się w literaturze przedmiotu o prymarnie mówionym charakterze sporej liczby gatunków internetowych (głównie tych wymienionych powyżej) są całkowicie przekonujące. W tekstach artystycznych zasłówki pojawiają się w partiach dialogowych lub monologowych, czyli znów jako elementy

${ }^{30}$ Bardzo podobnie można wyjaśnić funkcjonowanie w wypowiedziach onomatopei oraz czasowników onomatopeicznych. Wyrażenia onomatopeiczne (bez fleksji werbalnej) mogą zastępować - na zasadzie skojarzenia - pełnoznaczne czasowniki i funkcjonować jako wyrażenia predykatywne. Inna suboperacja tworzy z takich onomatopei morfologiczne czasowniki (np. kap $\Rightarrow$ kapać).

${ }^{31}$ Mówioność i okazjonalność to cechy, które przypisuje się (Majowa 1991: 26) wszystkim czasownikowym derywatom odzaimkowym typu tentegować, jakisić, tykać itd.

${ }^{32}$ Nie można zapominać, że część tych gatunków internetowych wywodzi się z gatunków istniejących wcześniej nie w postaci hipertekstowej (np. mail wywodzi się z listu, który jako gatunek ma bardzo długą historię). W teorii tekstu powszechnie przyjmuje się, że wiele tekstów internetowych to teksty de facto mówione - taką postać mogą mieć np. maile. 
potocznego języka mówionego, a przy dwu ostatnich wymienionych kategoriach tekstów mamy do czynienia z metatekstem, gdzie elementy wyłącznie mówione pojawiają się nie w zwykłym użyciu, ale w supozycji materialnej.

$\mathrm{Na}$ podstawie dotychczas przedstawionych obserwacji wprowadzić można pewną hierarchię funkcji pragmatycznych realizowanych przez AOZ. Funkcje charakterystyczne dla tekstów mówionych będą tu funkcjami pierwotnymi, natomiast funkcje charakterystyczne dla tekstów pisanych będą tu funkcjami wtórny$m i$ (przy czym taka funkcja wtórna w zasadzie jest jedna). Prymarnie opisywane w tym rozdziale jednostki języka wykorzystywane są do eufemizacji (funkcja eufemizująca) oraz jako tzw. podpórka przy zapomnieniu (funkcja hezytacyjna), natomiast wtórnie służą jako środek stylistyczny naśladujący w języku pisanym funkcje realizowane pierwotnie w tekstach mówionych (funkcja stylistyczna). W takim porządku funkcje te zostaną omówione w dalszej części podrozdziału.

Dąbrowska wspomina o eufemizacyjnej funkcji tentegować i onaczyć w kilku miejscach swojego studium o eufemizmach języka polskiego (2006: 304-305) oraz słownika eufemizmów (2005: 97, 102). Klasyfikuje ona te wyrażenia jako leksykalne środki eufemizowania w polu tematycznym ,życie seksualne”. Dosyć powszechnie ciągowi o postaci tentegować (a także ciągom o kwalifikacji wulgarnej) przypisuje się znaczenie „seksualne”. Takie stwierdzenia są jednak pewnymi uproszczeniami. Jeżeli tentegować i onaczyć nie są kształtami, na których opierają się leksykalne jednostki języka, a jedynie graficznymi (fonicznymi) wykładnikami asemantycznej operacji zastępowania pewnych czasowników, których znaczenie pozostaje w zdaniu wyjściowym, to taki zabieg eufemizacyjny jest raczej eufemizacją fonologiczną/graficzną, a nie leksykalną. To jest jednak kwestia zupełnie poboczna, gdyż typologię środków eufemizowania można skonstruować tak czy inaczej. Znacznie bardziej istotne jest przypisanie tego kształtu do konkretnego pola semantycznego. Jasne jest, że za tymi wyrażeniami nie kryje się żadne znaczenie inne niż dające się odczytać znaczenie kontekstowe (z dodatkowym nacechowaniem pragmatycznym) i nie można nie zauważyć, że taka słownikowa tendencja do wyodrębnienia dwóch znaczeń ('wykonywać dowolną czynność' i 'odbywać stosunek seksualny') jest obciążona błędem logicznym. Błąd ten jest widoczny na pierwszy rzut oka: w znaczeniu 'wykonywać dowolną czynność' mieści się znaczenie 'odbywać stosunek seksualny', ponieważ nie da się zaprzeczyć, że odbywanie stosunku seksualnego jest wykonywaniem pewnej czynności. Nie jest więc uzasadnione wyodrębnianie dwóch znaczeń, ponieważ już jedno z nich sensownie obejmowałoby wszystkie przypadki użycia analizowanego wyrażenia.

To, że istnieje tendencja, aby wyrażeniu tentegować przypisywać „znaczenie seksualne", bierze się po prostu z tego, że operacja o tym wykładniku wykorzystywana jest do eufemizowania, a eufemizuje się najczęściej jednostki leksykalne związane z seksualnością, fizjologią, sprawami intymnymi itp. W materiale mniej więcej połowa użyć dałaby się zakwalifikować jako „seksualne”. Nie uzasadnia to jednak mówienia, że jest to osobne znaczenie, bo gdyby tak było, trzeba by 
przypisać jeszcze dziesiątki następnych znaczeń, które w tekstach się pojawiają. Takie ,seksualne” znaczenie ma także swojego ,patrona”: w 1933 roku Karol Irzykowski ogłosił esej-pamflet Beniaminek. Rzecz o Boyu Żeleńskim. W nim stosuje wyrażenie tentegować jako środek eufemizujący (1933: 18). Co prawda nie pojawia się to w partii naśladującej język mówiony, ale jednocześnie jest to środek nawiązujący do zbyt „rozwiązłego” charakteru twórczości bohatera pamfletu:

Otrzymuje się wrażenie, że ten człowiek niczego więcej nie wymaga od świata, jak tylko odrobiny swobody płciowej, żeby się można więcej i częściej tentegować - ewangelią jego jest: „Dziateczki, miłujcie się nawzajem, ale ostrożnie - i pamiętajcie przy tym o Boyu!”

W kontekście nazwisk Boya i Irzykowskiego nie dziwi, że Nitsch nazwał tentegować słowem ,inteligenckim”33. Przywołany fragment z Beniaminka zacytował też Markiewicz (1974: 187) w wielokrotnie przedrukowywanym szkicu krytycznoliterackim z 1972 r. Jak był zrobiony „Beniaminek”, w którym fragment z Irzykowskiego zacytowany jest jako przykład chwytu retorycznego petitio principii. Nie jest przesadą twierdzenie, że beniaminkowe tentegowanie stało się czymś w rodzaju skrzydlatego słowa. Potwierdza to poniższy fragment z tekstu publicystycznego napisanego już w latach 70 . XX w.:

W większości więc żartów i obscenicznych wierszy, na ogół płaskich i trywialnych, chodziło o to - jak powiadał Irzykowski - żeby się więcej i częściej „tentegować” (Dynak 1977: 150)

Oczywiście Irzykowski nie jest „twórcą” wyrażenia tentegować. Ułaszyn w 1938 r. opublikował pracę poświęconą tzw. gwarze uczniowskiej, w której analizował materiał pochodzący z początku wieku zebrany od polskich studentów w Lipsku i w której rejestruje wyrażenia z tentegować (2009: 71, 93, 111-112). Co ciekawe, Ułaszyn podaje także dwa zasadnicze znaczenia, ale wśród nich nie ma znaczenia, które można by nazwać „,seksualnym”. Pierwsze (dla tentegować) to "czasownik używany w wypadku nienasunięcia się odpowiedniego czasownika', a drugie (dla ztentegować) 'cacare, pierdnąć, zesmrodzić się ${ }^{34}$. Dodatkowo jako czasowniki używane tak samo jak tentegować Ułaszyn wymienia wyczynić i wypiętrzycín.

${ }^{33}$ Tentegować - choć ,inteligenckie” - znane było także w gwarach. Potwierdza to nie tylko relacja Spytkowskiego, ale także materiał kartoteki Słownika gwar polskich, zob. Reichan (red.) (1999: 391). Warto jeszcze wspomnieć, że w 1934 r. Otrębski (1934: 24) wzmiankował istnienie w ,gwarze polskiej inteligencji” wyrażenia nie (ten) tego 'niedobrze'.

${ }^{34}$ Widać tu charakterystyczny dla dawnych prac filologicznych i leksykograficznych sposób eufemizowania słów związanych z cielesnością za pomocą podawania łacińskich odpowiedników przekładowych lub łacińskich terminów anatomicznych. Drugim potwierdzeniem używania wyrażenia tentegować na początku XX w. jest przywoływany już kilkukrotnie fragment wspomnień Spytkowskiego.

${ }^{35}$ Ułaszyn de facto posłużył się taką samą metodą ankietową, jak kilkadziesiąt lat później Kowalikowa, dlatego niewątpliwie jego dane też są niepełne. 
O ile jeszcze można zrozumieć uproszczenia, przekłamania i brak elementarnej logiki w pracach leksykograficznych, które powstają zwykle w dużym pośpiechu i bardzo rzadko są pracami nieinspirowanymi wcześniejszymi słownikami, o tyle już od prac leksykologicznych należałoby oczekiwać znacznie mniejszej nonszalancji w prezentowanej analizie. Tymczasem także w nich naszkicowane tu szablony opisu są bezrefleksyjnie (sic!) powielane. Np. w artykule Karwatowskiej i Szpyry-Kozłowskiej (2004) tentegować scharakteryzowane jest jako czasownik określający ,akt płciowy, aktywność mężczyzny”. Nie ma żadnych przykładów (jest za to długie wyliczenie synonimicznych czasowników realizujących to samo ,znaczenie”) i wzmianki o tym, czy takie znaczenie ma tentegować się (i czy w ogóle jest to coś odrębnego, czy nie). W rezultacie informacje o tentegować, które wyciągnąć można z tego artykułu, są właściwie bezwartościowe. Sięgając do materiału (zarówno internetowego, jak i literackiego), można wykazać, że konteksty bez się istotnie nazywają aktywność mężczyzn (pierwszy przykład), a gdy mówi się o ,aktywności kobiety”, pojawia się zaimek zwrotny (dwa kolejne przykłady):

Dostają fajny apartament dla nowożeńców, mąż zaczyna tentegować żonę, po czym znika nagle. (Internet)

- Zgrabna dziopa - mruknął Porucznik. - Z kim ona tu się tenteguje, ciekawym? Z Altenbergiem - powiedział w myślach Karol dziwiąc się, że go to gniewa. - Stary cap, niańki mu potrzeba. Co ona z nim robi? (T. Hołuj, Początek, 1978)

Już sobie wyobrażam rodziców, którzy tak wychowują: „każda szanująca się szmata tenteguje się z kolesiem na dyskotece, pamiętaj dziecko". (Internet)

Ale jednocześnie znaleźć można kontrprzykład, w którym „aktywność kobiet" oddawana jest czasownikiem bez się:

A że z nim tentegują, to może z miłości do niego? Klituś-bajduś, módl się za nami! Ginąć po prostu nie chcą od kuli tych Niemców-ludzi, ginąć, ot co! (J. Morton, Appassionata, 1976)

Oczywiście się wpływa na kontekstowe znaczenie tentegować (i każdego innego czasownika o znaczeniu ogólnym), ale tylko w ten sposób, że jest elementem „odziedziczonym” (podobnie jak prefiks i struktura predykatowo-argumentowa) po czasowniku wyjściowym, który decyzją mówiącego został poddany procesowi eufemizacji. Działanie tego mechanizmu dobrze pokazuje poniższy przykład:

I uważamy, by zbyt długo się nie jeba... ergh... nie tentegować, bo zostaniesz zarażony jakimś wirusem. (Internet)

Drugą pierwotną funkcją pragmatyczną realizowaną przez AOZ jest funkcja hezytacyjna (roboczo określana jako ,podpórka przy zapomnieniu”). W tym wypadku mówiący ma ograniczony wpływ na użycie tego, a nie innego 
wyrażenia, ponieważ przejęzyczenie czy zapomnienie, co się chciało powiedzieć, są procesami poza kontrolą ${ }^{36}$. Także w zasadzie poza kontrolą jest to, że zapobiegając przerwaniu potoku mowy, mówiący zwykle mają tendencję do umieszczania w wypowiedzi tzw. jęków namysłu, przerywników - słowem - tzw. pauz wypełnionych, czyli do tentegowania. W takich okolicznościach bardziej prawdopodobne jest umieszczenie przez mówiącego w toku komunikatu elementów znaczne krótszych typu $e, y$, ten, tego, tentego, które mają tę przewagę, że mogą pojawić się w dowolnej pozycji w zdaniu, nie tylko na miejscu czasownika (a przecież dalszy ciąg wypowiedzi może mówiącemu „wypaść z pamięci” w dowolnym miejscu zdania):

- E, tam, nie da. Wszystko się da, dziadek. Jak się postarasz, to wyrobisz w sobie, no, jak to się nazywa, ten tego. (J. Koprowski, Trou Madame, 1980)

Gdy jednak z pamięci w toku mowy „wypada” czasownik, wyrażenie tentegować może go zastąpić. Jest to szczególny wypadek operacji zasłówkowej, ponieważ czasownik wyjściowy nie jest mówiącemu (w tej konkretnej chwili lub nawet w ogóle) znany. Liczy on jednak, że odbiorca właściwie zdekoduje przekazywaną treść. Jednocześnie takie konteksty wyraźnie pokazują, że realizowana jest operacją, która dokonuje się w czasie mówienia:

Alkohol jest niezdrowy i od niego wątroba się, no... tego... tenteguje! Znaczy, psuje, niszczy! (Internet)

Omówione dwie funkcje pierwotne odwzorowywane są w tekstach literackich - jest to wtórne użycie elementów języka mówionego w charakterze środka stylistycznego. Pojawianie się w tej funkcji AOZ nie jest niczym wyjątkowym. Jest oczywiste, że do kolokwializacji swoich tekstów autorzy mogą wykorzystywać wszystkie cechy języka mówionego. Zasób wykładników zasłówkowości (choć stosunkowo ubogi) pozwala realizować nie tylko stylizację kolokwialną, lecz także wszystkie pozostałe podstawowe typy stylizacji. Przykłady użyć, w których tentegować wykorzystywane jest do kolokwializacji, już w toku wywodu były przywoływane. Tę funkcję stylistyczną dostrzegają także w swoich analizach literaturoznawcy:

${ }^{36}$ Autorzy starszych prac poświęconych zaburzeniom mowy wspominali o częstszym występowaniu u osób za afazją wyrażeń o znaczeniu ogólnym. Np. Jakobson (1964: 116) podawał francuskie: machin, chose i niemieckie: Ding, Stückle, überfahren przykłady rzeczowników i czasowników, które w afazji zastępują wyrażenia o konkretnym znaczeniu. Z kolei Zarębina podaje, że pacjenci z zaburzeniami neurologicznymi używają w funkcji uniwersalnych czasowników być, mieć, robić i używać (1973: 90-91), a tendencja afatyków do uogólnień przekłada się na istnienie w systemie ogólnym czasowników uniwersalnych - gwarowego onaczyć i wulgarnego, w jej odczuciu, tentegować, które stosuje się w przypadku zapomnienia nazwy czynności (1973: 178). 
Kompozycja tekstu sugeruje, że ich retoryka ma charakter instrumentalny. Zaprzeczają jej nie tylko zachowania partyzantów, którzy z wieśniakami postępują jak żołnierze okupanta, ale także napięcia stylistyczne noweli Różewicza. W dyskurs patriotyczny wielokrotnie wkradają się sformułowania niestosowne. Heroiczny język podważają potoczne, trywialne i rubaszne wtręty, np. krew przelewamy, a oni pospótkę tentegują. (Browarny 2008: 47)

Szczególnie dużo takich zabiegów stylistycznych jest w prozie powojennej odnoszącej się do czasów wojennych lub powojennych (ale już nie współczesnych, rozumianych jako epoka po roku 1989). Kilka przykładów przywoływanych już było wcześniej, dwa kolejne przytoczone zostają jeszcze poniżej:

\begin{abstract}
- Mam cię potąd! - wrzasnął Turoń - wynoś mi się, zaraz! I bez ciebie poradzę sobie, wywłoka tentegowana! Już, wstawać! - rękę wyciągnął, jakby za kark chciał go chwycić. Nie odważył się, cofnął rękę. Krzyczał za to jeszcze głośniej. (J. Putrament, Rozstaje, 1954) Zaczynałem drzemać... Czy to armaty tak tentegują? To oni tak rąbią siekierami drzwi, brzęczą szablami po pokojach plebani i zjadają ostatni konfitur? (L. Buczkowski, Jako ów tam ułan, 1976; fragment powieści Kamień w pieluszkach, 1978)
\end{abstract}

Być może jest tak, że współcześnie tentegować wycofuje się z mowy, ponieważ coraz słabiej działa tabu nałożone na wulgaryzmy. A nawet jeśli w codziennym języku częstość stosowania wulgaryzmów nie rośnie, to na pewno częściej pojawiają się one w tekstach literackich i tentegować jako eufemizm przestaje być użyteczne.

Ogląd zebranych kontekstów literackich pokazuje, że w pełni potwierdzone jest stwierdzenie, że AOZ są charakterystyczne dla języka mówionego - w prozie współczesnej wykładniki AOZ pojawiają się one wyłącznie w partiach dialogo$w_{y c h}{ }^{37}$. W dodatku są to dialogi w kontekstach sytuacji potocznych. Dlatego biorąc pod uwagę trzy podstawowe typy stylizacji, tentegować najczęściej niewątpliwie wykorzystywane może być do kolokwializacji. Z kolei onaczyć, które także ma obecnie charakter potoczny, jednocześnie może służyć zarówno do archaizacji (jako wyrażenie występujące w staropolszczyźnie), jak i do dialektyzacji (jako wyrażenia gwarowe - obecnie przede wszystkim kojarzone z gwarą śląską):

\title{
DWÓRKA I Z GRUPY GBURÓW
}

$\mathrm{Z}$ chłopem onaczyć się na sianie. (E. Bryll, Życie-jawa. Sztuka w 3 aktach z prologiem i epilogiem, 1973)

W ramach tych trzech typów stylizacji wskazać można na szczegółowe funkcje wartości stylistycznej, które potencjalnie realizowane mogą być przez $\mathrm{AOZ}^{38}$. Funkcje te można uporządkować w trzech grupach:

${ }^{37}$ Czyli w tych partiach tekstów prozatorskich, które Skudrzykowa (1994) nazywa językiem (za)pisanym i słusznie traktuje jako teksty pisane nierozerwalnie związane z językiem mówionym i oddające cechy mowy.

${ }^{38}$ Funkcję te wyodrębnione zostały za Dubiszem (1990), który opisuje funkcje realizowane w utworach literackich przez wykładniki archaizacji. 
I. Funkcje fabularne:

- etnograficzna - oddaje kulturowe różnice między postaciami utworu;

- indywidualizująca - różnicuje przekazu poszczególnych postaci utworu;

- intelektualna - pozwala różnicować postacie utworu ze względu na ich poziom umysłowy;

- psychologiczna - pozwala różnicować postacie utworu pod względem ich emocji i uczuć;

- socjologiczna - pozwala określić przynależność społeczną postaci lub ich społeczne zróżnicowanie.

II. Funkcje strukturalne:

- różnicująca - różnicuje podstawowe typy wypowiedzi (narracja, monolog, dialog);

- uzupełniająca - stanowi uzupełnienie innych składników tworzywa językowego tekstu.

III. Funkcje artystyczne:

- (anty)poetyzująca - wywołuje nastrój (anty)poetyckości (kolokwialności) tekstu;

- komiczno-humorystyczna - przyczynia się do komizmu postaci i sytuacji.

W całej gamie środków, z których może czerpać autor tekstu artystycznego, wykładniki $\mathrm{AOZ}$ to ledwie margines ${ }^{39}$. W praktyce zawsze występują one razem z wieloma innymi wykładnikami kolokwializacji.

\section{Podsumowanie}

Przedstawiona w niniejszym podrozdziale pragmatyczna interpretacja pewnego typu wyrażeń czasownikowych udowadnia, że w przypadku czasownikowych jednostek języka ich znaczenie jest związane nie tyle z morfologicznym kształtem leksykalnym, ile układem pozycji składniowych otwieranych przez daną jednostkę. Dlatego możliwe jest zastępowanie kształtów czasownikowych innymi kształtami bez zmiany znaczenia wypowiedzenia i odkodowywanie komunikatów, w których takie substytucje zaszły. Operacja zasłówkowa nie wnosi żadnej nowej wartości semantycznej - jej funkcje są wyłącznie pragmatyczne.

Przedstawiony opis zjawiska (choć pragmatyczny) ma charakter ściśle lingwistyczny - podstawowym punktem ,zaczepienia”, który pozwala na właściwie rozumienie zdań z czasownikami o znaczeniu ogólnym, jest tu bowiem struktura

${ }^{39} \mathrm{~W}$ większości prac materiałowych poświęconych analizie wykładników stylizacji kolokwialnej we współczesnych polskich tekstach prozatorskich zaimki czasownikowe nie były nawet wspomniane, zob. np. Witosz (1988), Skudrzykowa (1994), Święcicka (1999), Ignatowicz-Skowrońska (2000), co prawdopodobnie wynika z tego, że akurat nie występowały one w konkretnych tekstach analizowanych w poszczególnych monografiach. 
predykatowo-argumentowa będąca podstawą budowy składniowej i semantycznej zdania. Trudno jednak nie zauważyć, że w komunikacji mówionej istotny jest także szeroko rozumiany kontekst sytuacyjny, który dodatkowo ułatwia rozmówcom zrozumienie.

\section{Bibliografia}

Anusiewicz, J., Skawiński, J. 1996. Słownik polszczyzny potocznej, Warszawa: PWN.

Bańko, M. 2001. Z pogranicza leksykografii i językoznawstwa. Studia o słowniku jednojęzycznym, Warszawa: Wydział Polonistyki Uniwersytetu Warszawskiego.

Bartmiński, J. 1974. O pewnej różnicy między językiem pisanym a mówionym (zasada minimalizacji wyboru), „Prace Filologiczne” 25, 225-232.

Bartmiński, J. 1978. Swoiste formy orzeczeń w języku ustnym (orzeczenie onomatopeiczne, kompozycjonalne, zaimkowe, podwojone, [w:] Studia nad sktadnia polszczyzny mówionej, red. T. Skubalanka, Wrocław: Ossolineum, 159-175.

Bobrowski, I. 1982. Zasady organizacji haset czasownikowych o znaczeniu «ogólnym» w interpretatywnym leksykonie gramatyki transformacyjnej, [w:]. J. Tokarski (red.), Język. Teoria - dydaktyka V, Kielce: WSP, 124-131.

Bobrowski, I. 1985. Cechy subkategoryzacyjne polskich czasowników przechodnich, Wrocław: Ossolineum.

Bogusławski, A. 1976. O zasadach rejestracji jednostek języka, „Poradnik Językowy” 8 (56), 356-364.

Bogusławski, A. 1994. O niektórych operacjach asemantycznych $w$ języku polskim, [w:] P. Jacobsen, J. S. Jensen et al., En Slavist i humanismens tegn. Festskrift til Kristine Heltberg., Kobenhavn: Reitzels. 8-15.

Browarny, W. 2008. Proza życia Różewicza, „Odra” 10 (48), 10. 47.

Bugajski, M. 2006. Język w komunikowaniu, Warszawa: Wydawnictwo Naukowe PWN.

Chachulska, B. 1998. Analiza łączliwości składniowej polskich leksemów robić i czynić, „Polonica" $19,149-159$.

Czeszewski, M. 2006. Stownik polszczyzny potocznej, Warszawa: Wydawnictwo Naukowe PWN.

Dąbrowska, A. 2005. Słownik eufemizmów polskich, czyli w rzeczy mocno, w sposobie łagodnie, Warszawa: Wydawnictwo Naukowe PWN.

Dąbrowska, A. 2006. Eufemizmy wspótczesnego języka polskiego, Łask: Leksem.

Dean, G., I. Fahsing, P. Gottschalk.2010. Organized Crime. Policing Illegal Business Entrepreneurialism, New York: Oxford University Press.

Doroszewski, W. 1926. W sprawie zaimków czasownikowych, „Język Polski” 4 (11), 103-106.

Dubisz, S. 1990. Archaizacja w utworze literackim, „Poradnik Językowy” 8 (70), 592-599.

Dynak, J. 1977. „Jak baba mnie z góry - to ja ja z jesce wyzsa...” Góry, górale i sprawy górskie w prasie humorystycznej w latach 1890-1939, „Wierchy” 46, 134-154.

Ignatowicz-Skowrońska, J. 2000. Stylizacja na styl potoczny w prozie Marka Nowakowskiego, Szczecin: Uniwersytet Szczeciński.

Irzykowski, K. 1933. Beniaminek. Rzecz o Boyu Żeleńskim, Warszawa: Księgarnia F. Hoesicka.

[ISJP] Bańko, M. (red.). 2000. Inny słownik języka polskiego PWN, t. 1-2, Warszawa: Wydawnictwo Naukowe PWN.

Jakobson, R. 1964. Dwa aspekty języka i dwa typy zakłóceń afatycznych, [w:]. R. Jakobson, M. Halle, Podstawy języka, Wrocław: Ossolineum, 107-133.

Jawór, A. 2010. O pewnym typie ,językowego jokera”, „Kwartalnik Językoznawczy” 1 (2), 1-12. 
Jodłowski, S. 1973. Ogólnojęzykoznawcza charakterystyka zaimka, Wrocław: Ossolineum.

Karwatowska, M., J. Szpyra-Kozłowska. 2004. On, ona, seks i język polski, „Studia z Filologii Polskiej i Słowiańskiej" 39, 133-155.

Kempf, Z. 1972. O serbsko-chorwackich zaimkach czasownikowych, [w:]. Z polskich studiów slawistycznych, Ser. 4: Językoznawstwo,. Prace na VII Międzynarodowy Kongres Slawistów w Warszawie 1973, red. W. Doroszewski, Warszawa: PWN, 163-174.

Kizza, J. M. 2011. Computer Network Security and Cyber Ethics, Jefferson: McFarland.

Kowalikowa, J. 1991a. Czasownikowe sygnały emocji w mowie młodzieży krakowskiej, „Zeszyty Naukowe UJ. Prace Językoznawcze" 107, 131-143.

Kowalikowa, J. 1991b. Słownictwo młodych mieszkańców Krakowa, Kraków: UJ.

Kucała, M. 1960. O słownictwie ludzi wyzbywajacych się gwary, „Biuletyn Polskiego Towarzystwa Językoznawczego" 19, 141-156.

Lewinson, J. 1999. Słownik seksualizmów polskich, Warszawa: Książka i Wiedza.

Lipiński, K. 2004. Mity przekładoznawstwa, Kraków: Egis.

Majowa, J. 1991. Odzaimkowe formacje stowotwórcze w kaszubszczyźnie, „Studia z Filologii Polskiej i Słowiańskiej” 27, 25-32.

Markiewicz, H. 1974. Jak był zrobiony „Benjaminek”, [w:] Badania nad krytyka literacka, red. J. Sławiński, Wrocław: Ossolineum. 181-192.

Nitsch, K. 1926a. O zaimkach czasownikowych, „Język Polski” 3 (11), 65-69.

Nitsch, K. 1926b. Odpowiedź pp. Doroszewskiemu i Szoberowi, „Język Polski” 4 (11), 110-111.

Nitsch, K. 1955. Wybór pism polonistycznych, t. 2, Wrocław: Ossolineum.

Niziołek, A. 2001. Warunki anaforyzacji w modelu transformacyjno-generatywnym, „Polonica” 21, 203-210.

Otrębski, J. 1934. O pochodzeniu wyrazu ,niestety”, „Slavia Occidentalis” 34, 21-25.

Pęzik, P. 2012. Język mówiony w NKJP, [w:] A. Przepiórkowski i in. (red.), Narodowy Korpus Języka Polskiego, Warszawa: Wydawnictwo Naukowe PWN, 37-47.

Piernikarski, C. 1969. Typy opozycji aspektowych czasownika polskiego na tle stowiańskim, Wrocław: Ossolineum.

Piernikarski, C. 1990. Struktura syntaktycznych grup homogenicznych (w zestawieniu z niektórymi typami grup heterogenicznych), Wrocław: Ossolineum.

Pisarkowa, K. 1969. Funkcje sktadniowe polskich zaimków odimiennych, Wrocław: Ossolineum.

[PSWP] Zgółkowa, H. (red.). 1994-2005. Praktyczny słownik wspótczesnej polszczyzny, t. 1-50, Poznań: Kurpisz.

Reichan, J. (red.). 1999. Indeks alfabetyczny wyrazów z kartoteki „Słownika gwar polskich”, t. 2: $P-\dot{Z}$, Kraków: Instytut Języka Polskiego PAN.

[SJPDor] Doroszewski, W. (red.) 1997. Stownik języka polskiego PWN [CD-ROM], Warszawa: Wydawnictwo Naukowe PWN.

Skarżyński, M. 2004. Słownik gniazd słowotwórczych współczesnego języka ogólnopolskiego, t. 4: Gniazda motywowane przez liczebniki, przysłówki, zaimki, przyimki, modulanty, onomatopeje, wykrzykniki, Kraków: Historia Iagellonica.

Skudrzykowa, A. 1994. Język (za)pisany. O kolokwialności dialogów współczesnej prozy polskiej, Katowice: Uniwersytet Śląski.

Sławski, F. 1962. Zarys dialektologii południowosłowiańskiej z wyborem tekstów gwarowych, Warszawa: PWN.

Sobierajski, Z. 1960. Przydatność plyty gramofonowej w badaniach gwarowych metoda subiektywno-odstuchowa, „Biuletyn Fonograficzny - Bulletin Phonographique” 3, $29-48$.

Sobierajski, Z. 1985. Teksty gwarowe z zachodniej Wielkopolski, Wrocław: Ossolineum.

Sobierajski, Z. 1990. Teksty gwarowe z północnej Wielkopolski, Wrocław: Ossolineum. 
[SPR] Fleischer M. i in. (red). 2011. Stownik polszczyzny rzeczywistej (siła rzeczy fragment), Łódź: Verbum Primum.

Spytkowski, J. 1975. Folklor podkrakowski w moich wspomnieniach, „Język Polski” 1 (55), 53-55.

Szober, S. 1926. O czasownikach „,zaimkowych”, „,Język Polski” 4 (11), 106-110.

Śledź, A. 2000. Próba przedstawienia zależności składniowych polskich przerywników, „Prace Językoznawcze Uniwersytetu Warmińsko-Mazurskiego" 2, 161-168.

Śledź, A. 2003. Przerywnik czy wykrzyknik? Analiza składniowa i semantyczna pewnych użyć słów uważanych za wulgarne, „Poradnik Językowy” 9 (83), 69-74.

Święcicka, M. 1999. Kreacja dialogu potocznego we współczesnej prozie dla młodzieży, Bydgoszcz: Wyższa Szkoła Pedagogiczna.

Topolińska, Z. 1982. Srpskohrvatski ,zamenički” glagoli-nosioci replika u dialogu, „Zbornik za filologiju i lingvistiku" 1 (25), 151-160.

Topolińska, Z. 1987. O „pronominalizacji” wyrażeń werbalnych, „Прилози. МАНУ/ОЛЛН” 2 (12), $155-160$.

Topolińska, Z. 1989. O pewnej osobliwej słoweńskiej konstrukcji prowerbalnej, „Slavistična revija" 37, 97-102.

Topolińska, Z. 2008. Z Polski do Macedonii. Studia językoznawcze, t. 1: Problemy predykacji, Kraków: Lexis.

Ułaszyn, H. 2009. Studia onomastyczne i socjolingwistyczne, Poznań: Poznańskie Towarzystwo Przyjaciół Nauk.

[USJP] Dubisz, S. (red.). 2004. Uniwersalny słownik języka polskiego PWN [CD-ROM], Warszawa: Wydawnictwo Naukowe PWN.

Wańkowicz, M. 2010. Karafka La Fontaine’a, Warszawa: Prószyński i Sk-a.

Wawrzyńczyk, J. 1989. Nad stownikiem języka polskiego 1958-1969, Toruń: Uniwersytet im. Mikołaja Kopernika.

Witosz, B. 1988. Cechy strukturalno-sktadniowe monologu wypowiedzianego (na przyktadzie literatury polskiej), Katowice: Uniwersytet Śląski.

Wójcik, J. 2007. Przeciwdziałanie finansowaniu terroryzmu, Warszawa: Wolters Kluwer Polska.

Zarębina, M. 1973. Rozbicie systemu językowego w afazji (na materiale polskim), Wrocław: Ossolineum.

Żmigrodzki, P. 2000. Właściwości składniowe analitycznych konstrukcji werbo-nominalnych w języku polskim, Katowice: UŚ.

Żurowski, S. 2010. Propozycja opisu wyrażeń o tzw. znaczeniu ogólnym, „LingVaria” 1 (5), $103-111$.

Żurowski, S. 2011. Funkcje pragmatyczne operacji zasłówkowych, „Media - Kultura - Komunikacja Społeczna. Zeszyty Naukowe Instytutu Dziennikarstwa i Komunikacji Społecznej UWM" 7, 46-54.

Żurowski, S. 2012. Proverbality in Slavic Languages (An Outline of Issues), [w:]. E. Kislova, K. Knapik-Gawin et al. (red.), Beiträge der Europäischen Slavistischen Linguistik (POLYSLAV). Band 15, München: Otto Sagner, 322-328. 